\title{
AKTIVITAS ANTIBAKTERI SEDIAAN GEL ANTISEPTIK EKSTRAK ETANOL KULIT PISANG KEPOK MENTAH (Musa paradisiaca L.) TERHADAP BAKTERI Staphylococcus aureus DAN Staphylococcus epidermidis
}

\author{
Annisa Primadiamanti ${ }^{1}$, Selvi Marcellia ${ }^{1}$, Sigit Sukmawan ${ }^{1}$ \\ ${ }^{1}$ Jurusan Farmasi, Universitas Malahayati Bandar Lampung, Indonesia
}

\begin{abstract}
Antibacterial Activity of Antiseptic Gel Preparation Ethanol Extract of Raw Kepok Banana (Musa paradisiaca L.) Skin Against Staphylococcus aureus and Staphylococcus epidermidis Bacteria. Kepok banana peels contained tannins, flavonoids, alkaloids, and saponins that had the potential to be antibacterial agent. This study aimed to determine the antibacterial activity of the antiseptic gel preparation of the ethanol extract of raw kepok banana peels (Musa paradisiaca L.) against Staphylococcus aureus and Staphylococcus epidermidis bacteria with various extract concentrations. Kepok banana peel ethanol extract gel was made into 3 formulas with various concentrations (F1 $=0.5 \%$; FII $=$ $1.0 \%$; and FIII $=1.5 \%)$. Antibacterial activity test was carried out by using the diffusion method. The results showed that the concentration of raw kepok banana peel extract (Musa paradisiaca L.) in an antiseptic gel preparation which was effective in inhibiting the growth of Staphylococcus aureus and Staphylococcus epidermidis bacteria in each bacteria was $1.5 \%$. Better antibacterial activity of raw kepok banana peels (Musa paradisiaca L.) in antiseptic gel preparation was found in Staphylococcus aureus bacteria seen from the inhibition zone formed by $14.21 \mathrm{~mm}$.
\end{abstract}

Keywords: kepok banana peels, antiseptic gel, Staphylococcus aureus, Staphylococcus epidermidis

\begin{abstract}
Abstrak : Aktivitas Antibakteri Sediaan Gel Antiseptik Ekstrak Etanol Kulit Pisang Kepok Mentah (Musa Paradisiaca L.) Terhadap Bakteri Staphylococcus Aureus Dan Staphylococcus Epidermidis. Kulit pisang kepok mengandung senyawa tanin, flavonoid, alkaloid, dan saponin yang berpotensi sebagai antibakteri. Penelitian ini bertujuan untuk mengetahui aktivitas antibakteri pada sediaan gel antiseptik ekstrak etanol kulit pisang kepok mentah (Musa paradisiaca L.) terhadap bakteri Staphylococcus aureus dan Staphylococcus epidermidis dengan berbagai konsentrasi ekstrak. Gel ekstrak etanol kulit pisang kepok mentah dibuat menjadi 3 formula dengan variasi konsentrasi ( $F 1=0,5 \%$; $\mathrm{FII}=1,0 \%$; dan $\mathrm{FIII}=1,5 \%$ ). Uji aktivitas antibakteri dilakukan dengan metode difusi sumuran. Hasil penelitian menunjukkan bahwa konsentrasi ekstrak kulit pisang kepok mentah (Musa paradisiaca L.) pada sediaan gel antiseptik yang efektif dalam menghambat pertumbuhan bakteri Staphylococcus aureus dan Staphylococcus epidermidis pada masing-masing bakteri yaitu pada konsentrasi $1,5 \%$. Aktivitas antibakteri yang lebih baik dari gel ekstrak etanol kulit pisang kepok mentah (Musa paradisiaca L.) terdapat pada bakteri Staphylococcus aureus dilihat dari zona hambat yang terbentuk sebesar 14,21 mm.
\end{abstract}

Kata kunci : kulit pisang kepok, gel antiseptik, Staphylococcus aureus, Staphylococcus epidermidis

\section{PENDAHULUAN}

Gangguan kesehatan pada keberadaannya banyak tersebar di alam manusia yang paling umum diderita sekitar kita Penyebaran bakteri ini dapat adalah infeksi. Salah satu penyebab terjadi dengan cara kontak langsung infeksi adalah bakteri. Bakteri yang (bersentuhan, berjabatan tangan, dan paling banyak menyebabkan infeksi sebagainya) kemudian diteruskan adalah Staphylococcus aureus dan melalui mulut (Ni'maturrohmah, 2014). Staphylococcus epidermidis yang 
Penyakit yang disebabkan oleh Staphylococcus aureus yaitu infeksi saluran kemih, diare, sepsis, dan meningitis, sedangkan Staphylococcus epidermidis dapat menimbulkan infeksi seperti bisul, impetigo, selulitis, dan infeksi saluran kemih. Mengingat bakteri tersebut berbahaya bagi kesehatan manusia, maka perlu dilakukan penanggulangan atau pencegahan terhadap perkembangannya, salah satunya adalah dengan memanfaatkan bahan aktif dari tanaman yang dapat digunakan sebagai antibakteri atau menekan pertumbuhan bakteri. Salah satu tanaman yang dapat dimanfaatkan sebagai antibakeri adalah tanaman pisang kepok (Djuanda et al., 2012).

Antibiotik adalah obat yang digunakan untuk mencegah dan mengobati infeksi bakteri. Penggunaan antibiotik yang tidak tepat selain menjadi pemborosan secara ekonomi juga berbahaya secara klinis, yaitu resistensi bakteri terhadap antibiotik. Resistensi terjadi saat bakteri mengalami kekebalan dalam merespons antibiotik yang awalnya sensitif dalam pengobatan.(Kemenkes RI, 2017). Cara yang digunakan untuk menghindari terjadinya resistensi terhadap antibiotik yaitu digunakan alternatif lain dengan memanfaatkan tanaman yang berkhasiat sebagai obat.

Pisang kepok (Musa paradisiaca L.) merupakan tanaman yang dibudidayakan secara luas di daerah Lampung. Selain untuk bahan makanan, pisang juga kerap kali digunakan sebagai jamuan para tamu adapun berbagai jenis pisang yang terdapat di Lampung antara lain pisang susu, pisang mas, pisang kepok, pisang ambon lumut, pisang raja, dan lain-lain. Buah pisang yang telah dikonsumsi, kulitnya dibuang begitu saja, terutama pada kulit pisang kepok merupakan salah satu limbah rumah tangga yang menjadi sumber pencemar jika tidak diberdayakan dengan benar. Dari beberapa penelitian diketahui kulit pisang kepok terkandung senyawa flavonoid yang berpotensi sebagai antibakteri padahal kulit pisang ini bisa dimanfaatkan sebagai bahan baku obat antiseptik. Ekstrak etil asetat kulit pisang kepok (Musa paradisiaca L.) berfungsi sebagai antibakteri terhadap, Staphylococcus aureus dan Staphylococcus epidermidis dengan diameter hambat antara 9 sampai 12 mm (Ermawati, 2016).

Gel umumnya merupakan suatu sediaan semi padat yang jernih, tembus cahaya dan mengandung zat aktif. Gel merupakan sediaan semi padat yang digunakan pada kulit, sediaan tersebut berfungsi sebagai pembawa obat-obat topikal,sebagai pelunak kulit, atau pembalut pelindung atau pembalut penyumbat (oklusif), dispersi koloid mempunyai kekuatan yang disebabkan oleh jaringan yang saling berikatan pada fase terdispersi zat pembentuk gel digunakan sebagai pengikat dalam granulasi, koloid pelindung dalam suspensi, pengental untuk sediaan oral dan sebagai basis supositoria (Mutiara, 2015).

Pemakaian antiseptik (Hand Sanitizer) yang diaplikasian secara tepat dan benar merupakan cara termudah dan efektif untuk mencegah berjangkitnya penyakit seperti diare, kolera, ISPA, cacingan, flu, hepatitis A, dan bahkan flu burung. Dengan menggunakan antiseptik dapat lebih efektif menghilangkan mikroorganisme secara mekanis dari permukaan kulit dan dapat mengurangi adanya penyebab penyakit seperti virus, Bakteri dan parasit lainnya pada kedua tangan (Sari dan Isadiartuti, 2006).

Berdasarkan uraian diatas dan mengingat kegunaan kulit pisang kepok dapat menghambat pertumbuhannya bakteri yang terdapat di kulit maka penulis tertarik untuk melakukan uji aktivitas antibakteri kulit pisang kepok (Musa paradisiaca L.) terhadap bakteri Staphylococcus aureus dan Staphylococcus epidermidis dengan menggunakan metode difusi sumuran.

Penelitian ini bertujuan untuk mengetahui aktivitas antibakteri pada sediaan gel ekstrak kulit pisang kepok mentah (Musa paradisiaca L.) terhadap Staphylococcus aureus dan Staphylococcus epidermidis, untuk mengetahui konsentrasi yang efektif dalam menghambat pertumbuhan 
bakteri Staphylococcus aureus dan Staphylococcus epidermidis dan untuk mengetahui aktivitas antibakteri yang lebih baik dari gel ekstrak kulit pisang kepok mentah (Musa paradisiaca L.) terhadap bakteri Stapylococcus aureus atau Staphylococcus epidermidis.

\section{METODE PENELITIAN}

Alat-alat yang digunakan pada penelitian ini terdiri dari maserator, beaker glass, timbangan analitik, rotary evaporator, cawan porselin, oven, batang pengaduk, corong kaca, autoklaf, lampu spiritus, inkubator, labu ukur, ose, cawan petri, pinset, tabung reaksi, pemijar, lumpang dan alu, spatel, sudip, gelas ukur, alumunium foil, blank disc, jangka sorong, viskometer, pH meter.

Bahan yang digunakan pada penelitian ini kulit pisang kepok, etanol $96 \%$, akuadest, MHA, asam asetat, karbopol, HPMC, TEA, metil paraben, gliserin, Staphylococcus aureus dan Staphylococcus epidermidis, ATCC, TSA, $\mathrm{HCL}$, pereaksi mayer, dragendrof, bauchardad, $\mathrm{NH}_{4} \mathrm{OH} 25 \%$, alkohol, asam asetat anhidrat, logam $\mathrm{Mg}$, $\mathrm{Fecl} 3, \mathrm{HCL}$ pekat, $\mathrm{H}_{2} \mathrm{SO}_{4}$, larutan Mc Farland.

\section{Prosedur Penelitian Sterilisasi Alat dan Bahan}

Alat yang terbuat dari kaca disterilkan dengan menggunakan autoklaf pada suhu $121^{\circ} \mathrm{C}$ selama 15 menit. Alat-alat yang terbuat dari plastik disterilkan dengan alkohol $70 \%$.

Tabung reaksi yang disumbat kapas dan cawan petri, dibungkus dengan menggunakan kertas kopi, disterilkan dengan suhu 170-180 0C selama 2 jam. Autoclave digunakan untuk mensterilisasi alat-alat ukur, peralatan yang berukuran kecil, dan media kultur yang sebelumnya dibungkus dengan menggunakan kertas kopi, disterilkan dengan suhu $1210 \mathrm{C}$ selama 20 menit.

\section{Preparasi Sampel}

Sampel berupa kulit pisang kepok mentah(Musa paradisiaca L.) terlebih dahulu disortasi basah, selanjutnya dilakukan pencucian dengan air mengalir. Kemudian sampel dirajang untuk memudahkan proses pengeringan.
Disortasi kering lalu diserbukkan, kemudian dilakukan proses ekstraksi dengan metode maserasi.

\section{Ekstraksi Kulit Pisang Kepok (Musa paradisiaca $L$.)}

Sampel kulit pisang yang telah diambil dicuci bersih, kemudian dianginanginkan selama 2 hari, setelah kering sampel dihaluskan dengan menggunakan blender hingga menjadi serbuk. 500 gram simplisia dimasukan dalam botol atau wadah gelap ditambah dengan pelarut etanol $96 \%$ sampai terendam sempurna. Lalu didiamkan selama 1 hari sambil sesekali diaduk, setiap 24 jam dilakukan pergantian pelarut sampai pelarut yang digunakan menjadi bening. Kemudian saring menggunakan corong yang sudah dilapisi dengan kertas saring sehingga diperoleh maserat dan ampas. Maserat yang diperoleh ditampung sedangkan ampas yang diperoleh ditambah dengan etanol $96 \%$ untuk dimaserasi kembali sampai tersaring sempurna. Untuk memastikan ambil $5 \mathrm{ml}$ cairan dimasukan kedalam cawan penguap, panaskan menggunakan bunsen, jika tidak meninggalkan endapan maka proses maserasi telah selesai. Kemudian dipekatkan dengan menggunakan rotary evaporator pada suhu $50^{\circ} \mathrm{C}$ sehingga diperoleh ekstrak pekat (Majidah, 2014).

\section{Tabel 1. Hasil Ekstraksi Kulit Pisang} Kepok Mentah

\begin{tabular}{ccccc}
\hline $\begin{array}{c}\text { Jenis } \\
\text { Ekstrak }\end{array}$ & Pelarut & $\begin{array}{c}\text { Bobot } \\
\text { Sampel }\end{array}$ & $\begin{array}{c}\text { Bobot } \\
\text { Ekstrak }\end{array}$ & $\begin{array}{c}\text { Rendeme } \\
\mathbf{n} \\
(\mathbf{\%})\end{array}$ \\
\hline $\begin{array}{c}\text { Ekstrak } \\
\begin{array}{c}\text { Kental } \\
\text { (gel) }\end{array}\end{array}$ & $\begin{array}{c}\text { Etanol } \\
96 \%\end{array}$ & $\begin{array}{c}500 \\
\text { gram }\end{array}$ & 50 gram & $10 \%$ \\
\hline
\end{tabular}

\section{Penapisan Fitokimia}

Penapisan fitokimia dilakukan dengan mereaksikan pereaksi tertentu dengan metabolit sekunder yang terdapat di dalam ekstrak kulit pisang kepok. Penapisan fitokimia terhadap ekstrak kulit pisang meliputi penapisan terhadap keberadaan flavonoid, kuinon, saponin, tanin, alkaloid (Prihantini, 2018). 


\section{Alkaloid}

Pemeriksaan Golongan Senyawa alkaloid Simplisia ditambahkan dengan $\mathrm{HNO}_{3}$ encer digerus dalam mortir, lalu ditambahkan beberapa $\mathrm{mL}$ kloroform sambil di gerus sampai homogen. Kemudian disaring, setelah disaring filtrat dikocok dengan $\mathrm{HCl}$. Lapisan asam dipisahkan, kemudian dibagi menjadi 3 bagian. Bagian pertama digunakan sebagai blangko, bagian kedua ditetesi dengan larutan pereaksi Mayer dan bagian ketiga ditetesi pereaksi Dragedorff. Hasil positif adanya alkaloid bila terbentuk endapan putih dengan pereaksi Mayer, dan jingga dengan pereaksi Dragendorff.

\section{Flavonoid}

Pemeriksaan Golongan Senyawa Flavonoid Simplisia di gerus dalam mortir dengan sedikit air, kemudian dimasukkan ke dalam tabung reaksi yang berisi logam $\mathrm{Mg}$ dan larutan $\mathrm{HCl}$. Seluruh campuran dipanaskan beberapa saat. Kemudian filtrat ditambah amil alkohol dan dikocok kuat-kuat. Adanya flavonoid akan menyebabkan filtrat berwarna merah.

\section{Tanin}

Pemeriksaan Golongan Senyawa Tanin Simplisia digerus dalam mortir dan dipanaskan dengan air di penangas air, lalu disaring. Filtrat di tambahkan dengan larutan gelatin $1 \%$, adanya endapan putih menunjukkan bahwa dalam simplisia terdapat tanin.

\section{Steroid}

Pemeriksaan Golongan Senyawa Triterpenoid dan Steroid Simplisia disari dengan eter, kemudian sari eter diuapkan hingga kering. Pada residu ditetesi larutan perekasi LiebermanBurchard. Penambahan pereaksi dilakukan dalam keadaan dingin. Terbentuknya warna ungu menunjukkan bahwa dalam simplisia terkandung senyawa kelompok triterpenoid, sedangkan bila terbentuk warna hijaubiru menunjukkan adanya senyawa kelompok steroid.

\section{Saponin}

Beberapa $\mathrm{mL}$ ekstrak sampel ditambahkan dengan $\mathrm{mL}$ air sambil dikocok selama 1 menit, lalu ditambahkan 2 tetes $\mathrm{HCl} 1 \mathrm{~N}$. Apabila busa yang terbentuk tetap stabil selama kurang lebih 10 menit, maka ekstrak negatif mengandung saponin.

\section{Tabel 2. Hasil Skrining Fitokimia Kulit Pisang Kepok}

\begin{tabular}{|c|c|c|}
\hline Identifikasi & $\begin{array}{c}\text { Hasil } \\
\text { Pengamatan }\end{array}$ & Keterangan \\
\hline Flavanoid & Terbentuk & + \\
\hline & $\begin{array}{l}\text { warna jingga } \\
\text { ringan }\end{array}$ & \\
\hline Alkaloid & Terbentuk & + \\
\hline & $\begin{array}{l}\text { warna merah } \\
\text { jingga }\end{array}$ & \\
\hline Tanin & $\begin{array}{l}\text { Terbentuk } \\
\text { warna biru }\end{array}$ & + \\
\hline Steroid & $\begin{array}{l}\text { Terjadi } \\
\text { perubahan } \\
\text { warna hijau } \\
\text { gelap mendekati } \\
\text { warna jingga }\end{array}$ & + \\
\hline Saponin & $\begin{array}{l}\text { Tidak terbentuk } \\
\text { busa dan busa } \\
\text { dihasilkan } \\
\text { sedikit } \\
\text { stabil }\end{array}$ & - \\
\hline
\end{tabular}

\section{Pembuatan Sediaan Gel}

Sediaan gel dikerjakan dengan 46 cara basis gel karbopol 940 dan HPMC kembangkan dengan akuades $70^{\circ} \mathrm{C}$ dalam gelas kimia, diaduk hingga mengembang. Kemudian TEA dicampurkan ke dalam basis lalu dihomogenkan. Ditambahkan metil paraben yang sebelumnya telah dilarutkan dengan $3 \mathrm{ml}$ aquadest pada suhu $70^{\circ} \mathrm{C}$, dihomogenkan. Dilarutkan ekstrak kulit pisang kepok (Musa paradisiaca L.) ke dalam gliserin, lalu dimasukkan ke dalam basis sedikit demi sedikit, dihomogenkan. Kemudian sisa air ditambahkan setelah itu dihomogenkan. Setelah gel jadi dilakukan evaluasi (Dewi, 2015). 


\section{Uji Antibakteri}

Uji aktivitas antibakteri dilakukan dengan metode difusi agar, menggunakan paper disc berdiameter 6 $\mathrm{mm}$. Pengujian daya hambat bakteri Staphylococcus aureus dan Staphylococcus epidermidis dilakukan dengan menyiapkan cawan petri yang berisi $20 \mathrm{~mL}$ media MHA (Mueller Hinton Agar). Oleskan suspensi bakteri uji secara merata menggunakan kapas lidi steril dengan cara swab dan biakan permukaan agar mengering. Dibuat sumuran dengan pada media agar dan beri label pada masing-masing lubang masing-masing konsentrasi serta kontrol negatif dan positif. Setelah diberi label

\section{HASIL}

Sampel yang digunakan dalam penelitian ini adalah kulit pisang kepok mentah (Musa paradisiaca L.) yang dideterminasi di laboratorium FMIPA Universitas Lampung menurut sistem klarifikasi Cronquist (1981). Determinasi bertujuan untuk mengetahui dan dimasukkan konsentrasi gel kedalam lubang sumuran. Perlakuan ini diulang sebanyak tiga kali. Cawan agar di inkubasi selama $1 \times 24$ jam pada suhu $37^{\circ} \mathrm{C}$. Setelah di inkubasi, zona hambatan yang terbentuk diamati dan diukur (Mahmudah dan Atun, 2017).

\section{ANALISIS DATA}

Data hasil pengujian daya hambat sediaan gel ekstrak kulit kulit pisang kepok mentah (Musa paradisiaca L), dianalisis menggunakan uji statistik Analisis of Varian (ANOVA) dengan taraf kepercayaan $95 \%$ Kemudian dilanjutkan dengan Post-Hoc Least Significant Difference (LSD).

memastikan kebenaran identitas tanaman yang akan digunakan dalam penelitian untuk menghindari kesalahan pengambilan sampel yang digunakan dalam penelitian adalah benar kulit pisang kepok mentah (Musa paradisiaca L.)

Tabel 3. Hasil Uji Antibakteri pada Sediaan Gel

\begin{tabular}{|c|c|c|c|c|c|c|}
\hline \multirow[t]{2}{*}{ Bakteri } & \multirow{2}{*}{$\begin{array}{l}\text { Kelompok } \\
\text { Perlakuan }\end{array}$} & \multicolumn{3}{|c|}{$\begin{array}{l}\text { Diameter Rata-Rata Zona } \\
\text { Hambat Pengulangan }\end{array}$} & \multirow{2}{*}{$\begin{array}{c}\text { Rerata Zona } \\
\text { Hambat } \pm \\
\text { SD }(\mathbf{m m})\end{array}$} & \multirow[t]{2}{*}{$\mathbf{P}$} \\
\hline & & $\mathbf{I}$ & II & III & & \\
\hline \multirow{5}{*}{$\begin{array}{l}\text { Staphylo } \\
\text { coccus } \\
\text { epidermi } \\
\text { dis }\end{array}$} & FI & 9.12 & 9.16 & 9.19 & $9.15 \pm 0.35$ & \multirow{5}{*}{0,00} \\
\hline & FII & 11.15 & 11.19 & 11.20 & $11.18 \pm 0,26$ & \\
\hline & FIII & 13.17 & 13.27 & 13.25 & $13.23 \pm 0,52$ & \\
\hline & K- & 6.11 & 6.14 & 6.23 & $6.16 \pm 0.62$ & \\
\hline & $\mathrm{K}+$ & 17.16 & 17.21 & 16.19 & $17.18 \pm 0.25$ & \\
\hline \multirow{5}{*}{$\begin{array}{l}\text { Staphylo } \\
\text { coccus } \\
\text { aureus }\end{array}$} & FI & 10.11 & 9.16 & 10.24 & $10.18 \pm 0.66$ & \multirow{5}{*}{0,00} \\
\hline & FII & 11.14 & 11.19 & 11.22 & $11.18 \pm 0.40$ & \\
\hline & FIII & 14.16 & 13.27 & 14.21 & $14.19 \pm 0.26$ & \\
\hline & $\mathrm{K}-$ & 7.10 & 6.14 & 7.18 & $7.14 \pm 0.40$ & \\
\hline & $\mathrm{K}+$ & 16.18 & 17.21 & 16.25 & $16.21 \pm 0.35$ & \\
\hline
\end{tabular}




\section{PEMBAHASAN}

Serbuk simplisia diekstrak dengan etanol 96\% sebanyak 4 liter dengan metode maserasi. Alasan penggunaan pelarut etanol $96 \%$ menurut Tiwari,et al (2011). Lebih efisien dalam degradasi dinding sel sehingga polifenol lebih banyak tersaring. Selain itu etanol juga merupakan pelarut universal yang mudah didapat serta murah harganya dengan indeks polaritas 5,2 sehingga berbagai senyawa baik polar maupun non polar seperti senyawa flavonoid, saponin, alkaloid dan tanin yang terdapat pada kulit pisang kepok dapat tertarik oleh pelarut (Cahyani dan Hermanto, 2019).

Pada penelitian ini dilakukan skrining fitokimia yang bertujuan untuk mengidentifikasi kandungan senyawa kimia yang terdapat pada ekstrak kulit pisang kepok. Identifikasi golongan senyawa bioaktif yang berpotensi sebagai antibakteri dilakukan terhadap empat jenis senyawa fitokimia. Senyawa fitokimia tersebut adalah flavanoid, alkaloid ,tanin dan steroid dan triterpenoid Skrining fitokimia dilakukan secara kualitatif berdasarkan pada sifat kelarutan senyawa. Hasil skrining fitokima ekstrak kulit pisang kepok positif mengandung senyawa flavonoid, tanin, alkaloid dan steroid (dapat dilihat pada tabel 2).

Metode yang digunakan dalam uji aktivitas bakteri adalah metode sumuran yaitu dengan membuat lubang pada media Mueller Hinton Agar (MHA). Alsan penggunaan media MHA karena media MHA mengandung starch yang dapat menyerap toksik yang dikeluarkan oleh bakteri dan juga rendah sulfonamide, trimethorprin dan tetracyclin inhibitor, mendukung pertumbuhan bakteri non fastidious yang patogen. Alasan metode sumuran yang digunakan dibandingan metode cakram disk adalah metode sumuran terjadi osmolaritas dari konsentrasi yang lebih tinggi dari metode disk. Metode sumuran setiap lubang dimasukkan sediaan gel sehingga osmolaritas terjadi lebih menyeluruh dan lebih homogen dan lebih kuat untuk menghambat pertumbuhan bakteri (Wahyuni, 2009).
Sedangkan dengan metode difusi disk, cakram disk harus direndam di dalam cawan petri yang berisi gel lalu diletakkan diatas agar. Sehingga, diasumsikan volume gel yang dapat diserap kertas cakram berbeda setiap perlakuan. Sebagai kontrol negatif yang digunakan formulasi gel tanpa ekstrak. Gel hand sanitizer merk aseptic gel digunakan sebagai kontrol positif.Masing-masing bakteri Staphylococcus aureus dan Staphylococcus epidermidis diinokulasi dalam tabung yang berisi $\mathrm{NaCl} 0,9 \%$. Bakteri yang diinokulum dihitung berdasarkan tingkat kekeruhan yaitu sesuai dengan standar Mac. Farland 0,5 sehingga setara dengan suspensi bakteri yang mengandung 4×109 koloni bakteri per $\mathrm{ml}$ (Prihandani et al, 2015). Hasil penelitian menunjukkan bahwa seluruh konsentrasi uji yang digunakan $0,5 \%, 1 \%$ dan $1,5 \%$ memiliki aktivitas antibakteri terhadap bakteri Staphylococcus aureus dan Staphylococcus epidermidis.

Dari hasil pengamatan diameter zona hambat, konsentrasi hambat minimum (KHM) terdapat pada konsentrasi $0,5 \%$ dengan diameter $10,1833 \mathrm{~mm}$ terhadap bakteri Staphylococcus aureus dan 9,1567 mm terhadap bakteri Staphylococcus epidermidis. Konsentrasi $1 \%$ mampu menghambat pertumbuhan bakteri dengan diameter $11,1800 \mathrm{~mm}$ bakteri Staphylococcus aureus dan 11,1800 $\mathrm{mm}$ terhadap bakteri Staphylococcus epidermidis. Konsentrasi 1,5\% mampu menghambat pertumbuhan bakteri dengan diameter $14,1900 \mathrm{~mm}$ bakteri Staphylococcus aureus dan 13,2300 $\mathrm{mm}$ terhadap bakteri Staphylococcus epidermidis. Berdasarkan penilitian tersebut menunjukkan bahwa ekstrak kulit pisang kepok berpotensi dapat digunakan dalam mengobati infeksi yang disebabkan oleh bakteri Staphylococcus aureus dan Staphylococcus epidermidis dengan kategori sedang hingga kuat Besaran zona hambat meningkat seiring dengan penambahan konsentrasi ekstrak Gel hand sanitizer merk aseptic gel digunakan sebagai kontrol positif. 
Uji statistik pada penelitian ini adalah dengan menggunakan ANOVA. Sebelum dilakukan analisa data menggunakan ANOVA terlebih dahulu diuji normalitas bertujuan untuk menguji apakah data bahan uji gel ekstrak kulit pisang kepok mentah (Musa paradisiaca L.).

menyebar (terdistribusi) secara normal atau tidak. Dari hasil uji shapiro-wilk terhadap masing-masing kontrol uji didapatkan bahwa data terdistribusi normal $(p>0,005)$ sehingga diteruskan dengan uji parametrik ANOVA.

Dari data statistik ANOVA sediaan gel ekstrak kulit kulit pisang kepok mentah (Musa paradisiaca L.) didapatkan nilai signifikan 0,000 yang artinya terdapat perbedaan signifikan, sehingga dapat dilakukan uji lanjut LSD (Least Significant Differences). Berdasarkan hasil uji LSD (Least Significant Differences) bahwa sediaan gel ekstrak kulit pisang kepok mentah (Musa paradisiaca L.) dengan berbagai konsentrasi memberikan efektivitas antibakteri yang bermakna terhadap kontrol negatif karena nilai $(P<0,05)$. Kemudian dibandingkan dengan kontrol positif untuk mengetahui konsentrasi ekstrak kulit pisang kepok mentah(Musa paradisiaca L.) yang aktivitas antibakteri setara dengan aseptic gel. Hasilnya adalah sediaan gel ekstrak kulit pisang kepok mentah (Musa paradisiaca L.) dengan berbagai konsentrasi menunjukkan adanya perbedaan bermakna $(P<0,05)$ terhadap kontrol positif. Dari hasil tersebut dapat dinyatakan bahwa sediaan gel ekstrak kulit pisang kepok mentah (Musa paradisiaca L.) tidak sebanding dengan kontrol positif. Kemudian kontrol positif menunjukkan adanya perbedaan bermakna $(P<0,05)$ terhadap kontrol negatif, artinya kontrol negatif tidak sebanding dengan kontrol positif. Hal ini dikarenakan penggunaan metode yang berbeda antara ekstrak dan sediaan gel ekstrak kulit pisang kepok mentah (Musa paradisiaca $L$ ).

$\begin{array}{ccc}\text { Namun } & \text { pada bakteri } \\ \text { Staphylococcus } & \text { aureus diameter }\end{array}$ untuk mengetahui kelunakan sediaan gel ekstrak kulit pisang kepok mentah hambatan dengan konsentrasi $0,5 \%$, $1 \%$ dan $1,5 \%$ lebih besar dibandingkan bakteri Staphylococcus epidermidis. Hal ini dikarenakan $\mathrm{Hal}$ ini dikarenakan Staphylococcus epidermidis lebih resisten terhadap senyawa yang terdapat dalam kulit pisang kepok mentah (Musa paradisiaca L) yaitu tanin, karena dinding sel Staphylococcus epidermidis lebih kompleks dibandingkan dengan Staphylococcus aureus.

Fungsi kontrol negatif adalah untuk mengetahui apakah bahan tambahan dalam pembuatan gel yang digunakan mempunyai sensitivitas terhadap bakteri. Kontrol negatif yang digunakan yaitu formula tanpa penambahan ekstrak menunjukkan tidak ada zona hambat pada pengujian terhadap bakteri Staphylococcus aureus dan Staphylococcus epidermidis. Hal ini mengindikasikan bahwa kontrol negatif yang digunakan tidak berpengaruh pada uji antibakteri. Sedangkan fungsi kontrol positif adalah sebagai pembanding apakah gel hand sanitizer ekstrak kulit pisang kepok memiliki sensitivitas yang sama dengan gel hand sanitizer buatan pabrik yang digunakan.Pada penelitian ini dilakukan beberapa uji stabilitas fisik gel, seperti pengamatan organoleptis, $\mathrm{pH}$, daya sebar, dan homogenitas. pengujian ini dilakukan sebagai acuan karakteristik sifat fisik gel yang baik. Pengamatan organoleptis pada sediaan gel ekstrak kulit pisang kepok.

Uji organoleptik meliputi bentuk, warna, dan bau. Gel yang dihasilkan berbentuk setengah padat yang merupakan karakteristik dari gel pada umumnya. Warna coklat merupakan hasil dari ekstrak kulit pisang kepok namun gel yang dihasilkan tidak transparan (tembus cahaya), hal ini dikarenakan konsentrasi ekstrak yang digunakan terlalu tinggi. Semakin tinggi konsentrasi ekstrak yang terkandung maka warna yang terbentuk akan semakin gelap. Uji daya sebar merupakan pengujian yang dilakukan

saat dioleskan kekulit dan telapak tangan manusia. Semakin besar 
diameter daya sebar maka semakin tinggi kecepatan gel menyebar dan mudah diusapkan dikulit. Hasil daya daya sebar gel dengan konsentrasi eksrak $0,5 \%, 1 \%$ dan $1,5 \%$ memenuhi persyaratan, yaitu berada direntang 5$7 \mathrm{~cm}$ (Ansel, 2008).

Uji pH dilakukan untuk mengetahui kestabilan suatu sediaan dan sediaan tersebut aman atau tidak terjadi iritasi bila digunakan pada kulit manusiaDari hasil pengukuran $\mathrm{pH}$ sediaan gel ekstrak kulit pisang kepok mentah dengan konsentrasi $0,5 \%, 1 \%$ dan $1,5 \%$. Nilai $\mathrm{pH}$ yang dihasilkan pada sediaan gel memenuhi persyaratan $\mathrm{pH}$ kulit yaitu 4,5-6,5 (Ibrahim, 2018). Uji homogenitas semua formulasi menunjukkan homogen yang ditandai dengan tidak terdapat butiran kasar pada gel. Hal ini sesuai dengan persyaratan homogenitas gel yaitu harus menunjukkan susunan yang homogen dan tidak terlihat butiran kasar (Cahyani dan Hermanto, 2019).

\section{KESIMPULAN}

Terdapat aktivitas antibakteri pada gel ekstrak kulit pisang kepok mentah (Musa paradisiaca L.) terhadap Staphylococcus aurus dan Staphylococcus epidermidis dilihat zona hambat yang terbentuk pada masingmasing dengan kategori sedang. Konsentrasi ekstrak kulit pisang kepok mentah (Musa paradisiaca L.) pada sediaan gel yang efektif dalam menghambat pertumbuhan bakteri Staphylococcus aureus dan Staphylococcus epidermidis pada masing-masing bakteri yaitu pada konsentrasi $1,5 \%$. Aktivitas antibakteri pada gel ekstrak kulit pisang kepok mentah (Musa paradisiaca L.) lebih baik pada bakteri Staphylococcus aureus dibandingkan dengan bakteri Staphylococcus epidermidis.

\section{DAFTAR PUSTAKA}

Ansel, H. C. (2008). Pengantar Bentuk Sediaan Farmasi, ed IV, Jakarta : UI-Press Alih bahasa Ibrahim, F.

Cahyani, S., \& Hermanto, H. (2019). Pengaruh Lama Dan Suhu
Pengeringan

Terhadap

Karakteristik Organoleptik, Aktivitas Antioksidan Dan Kandungan Kimia Tepung Kulit Pisang Ambon (Musa Acuminata Colla). Jurnal Sains dan Teknologi Pangan, 4(1).

Dewi, L. R. (2015). Optimasi Formula Krim W/O Ekstrak Etanolik Kulit Pisang Ambon (Musa paradisiaca L.) Dengan Variasi Kombinasi Span 80 dan Mineral Oil (Doctoral dissertation, Universitas Gadjah Mada). diambil dari saliva pasien Rumah, S., \& Gigi, S. Kemampuan air rebusan daun salam (Eugenia polyantha $W$ ) dalam menurunkan jumlah koloni bakteri Streptococcus sp Skripsi. Fakultas Tekologi Pertanian. Institut Pertanian Bogor.

Djuanda, A., Hamzah, M., \& Aisah, S. (2007). Ilmu penyakit kulit dan kelamin edisi kelima. Jakarta: Balai penerbit FKUI, 89-105.

Ermawati, W. O. (2016). Kajian pemanfaatan limbah kulit pisang raja (Musa paradisiaca var Raja) dalam pembuatan es krim. Jurnal Sains dan Teknologi Pangan, 1(1).

Ibrahim, R. (2018). Uji Aktivitas Antibakteri Fraksi n-heksana Kulit Buah Citrus reticulata Terhadap Bakteri Escherichia coli Dengan Metode Difusi Cakram (Doctoral dissertation, University of Muhammadiyah Malang).

Mahmudah, F. L., \& Atun, S. (2017). Uji aktivitas antibakteri dari ekstrak etanol temukunci (Boesenbergia pandurata) terhadap bakteri Streptococcus mutans. Jurnal Penelitian Saintek, 22(1), 59-66.

Mutiara, R. (2015). Formulasi Masker $\mathrm{Gel}$ Peel Off Antioksidan Mengandung Ekstrak Kulit Batang Kayu Manis (Cinnamomum burmanni Nees ex Bl.) (Doctoral dissertation, Fakultas MIPA (UNISBA).

Ni'Maturrohmah,W.(2014). Pemanfaat an Limbah Kulit Buah Pisang Kepok (Musa paradisiaca) Sebagai Bahan Dasar Pembuatan Cuka Organik Dengan Penambahan Acetobacter 
aceti Dengan Konsentrasi Yang

Berbeda (Doctoral dissertation,

Universitas Muhammadiyah

Surakarta).

Sari, R., \& Isadiartuti, D. (2006). Studi efektivitas sediaan gel antiseptik tangan ekstrak daun sirih (Piper betle Linn). Majalah Farmasi Indonesia, 17(4), 163-169.

Wahyuni, N. K. D. M. S., Rita, W. S., \& Asih, I. A. R. A. (2019). Aktivitias Antibakteri Ekstrak Kulit Pisang Kepok Kuning (Musa paradisiaca L.) Terhadap Bakteri Staphylococcus aureus dan Escherichia coli Serta Penentuan Total Flavonoid dan Fenol Dalam Fraksi Aktif. Jurnal Kimia (Journal of Chemistry), 9-15. 